\title{
THE DEVELOPING OF PROTOTYPE TOOLDETERMINING CELESTIAL POSITIONS (WAH 1.0) AS LEARNING MEDIA IN EARTHAND SPACE SCIENCE COURSE
}

\author{
Wiji Aziiz Hari Mukti ${ }^{1}$ and Ahmad Walid ${ }^{2}$ \\ ${ }^{1}$ State Islamic Institute of Bengkulu \\ Bengkulu, 38211, Indonesia \\ wijiazizharim@yahoo.com \\ ${ }^{2}$ State Islamic Institute of Bengkulu \\ Bengkulu, 38211, Indonesia \\ ahmad.walid51@yahoo.com
}

\begin{abstract}
Abstrak
The purpose of this study is a media creation for the deciding tool revealed that the position of the heavenly bodies can be created and used to determine the position of the heavenly bodies so that it can be used as a learning media in the Earth and space science course. The working principle of this tool is to use the coordinates of the horizon. Tools used i.e. compass, bows, tripod and camera. To test the accuracy of the application use stellarium mobile version 1.25. The results of this study are to test the accuracy of the altitude angle obtained its accuracy level results $100 \%$. Whereas, in order to test the accuracy of the altitude reached the corner of $99.86 \%$.
\end{abstract}

Keywords: determining the position of heavenly bodies tool WAH 1.0, learning media, horizon coordinates 


\section{Introduction}

We know that, learning the Nature of Science (NoS) is inseparable from learning media use the form tool demonstrations and experiments. Learning the NoS can take active and effective, if already available equipment or adequate learning media. Arsyad in Wulandari (2015) stated that the media can contribute to learning delivery learning messages can be more standard, learning can be more interesting, more interactive learning by applying theory study, implementation time of learning can be shortened, the quality of learning can be improved, the process of learning can take place whenever and wherever needed, the positive attitude of the students towards the learning material and learning process can in increase, and the role of a teacher morph into a positive direction. The reality in the field, many of the school campus which is still even minimal media/tools needed. According to the NRC (1996), in the professional development of teachers, teaching skills should be given, so that candidates can develop his skills, understanding and knowledge. The facts in the field find that learning Earth and Space Science (ESS) in schools and colleges has not been backed up with practical activities. ESS is dominated by learning lectures, Question and answer, and the assignment. Teachers have never taught the ESS through laboratory activities. As one branch of NoS, ESS should be learned through practical activities, because of the practical work is an integral part of teaching and learning activities. This is in line with the findings of the MoE, that learning science in school generally theoretical, through lectures, discussions, and problem resolution, no experiments or demonstration. To this many common reasons expressed, among other things because the teacher had never trained to carry out practical work, absence of laboratory space, and no practical tools.

Learning media needs is also indispensable for natural science education study program recently in IAIN Bengkulu especially in ESS course. On this dominant course filled with the submission of material in the lecture or discussion given the equipment for doing demonstrations or experiments are very expensive and much of its existence. To conduct observations of astronomical objects, require a telescope (telescope has the cheapest rates above 1.5 million) and the nearby province of Bengkulu Observatory is an Observatory Bosscha in Bandung. While the tools to determine the position of the heavenly bodies has never been anybody makes. It is based on observations of the researchers over the years. Based on those needs, researchers tried to make a media learning researcher name the tool position determining celestial WAH. WAH 1.0 which is the initials of the author and the use of this medium is that it suggests the 1.0 as the first media. Researcher hope, this media will experience continuous improvement.

ESS course is the study of astronomical objects. One of subject matter in ESS course was a different positioning of the sky. There is some coordinate system to define the position of the heavenly bodies are examined in the field of space science. This tool uses one of the coordinate system is the coordinate system i.e. the horizon which in term is used coordinate azimuth and altitude. Determination of the azimuth and altitude illustrated in Figure 1. 


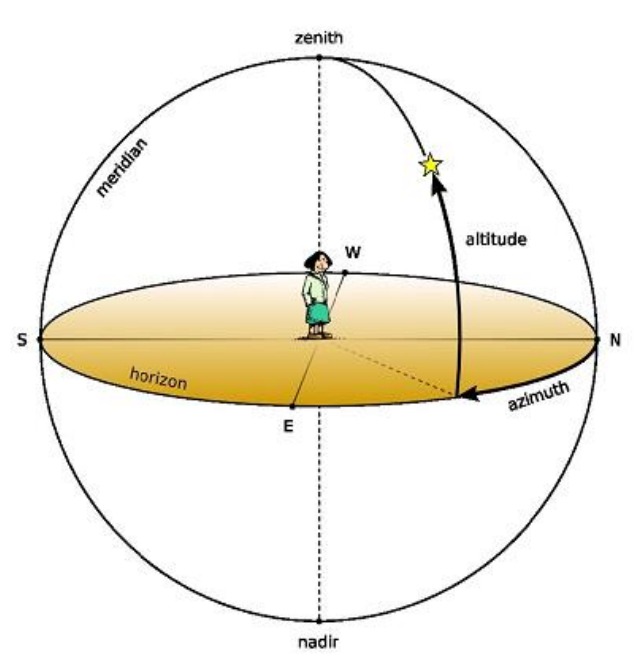

Figure 1 Tata horizon coordinates

The Zenith is the point above the head, nadir is the point under the foot, the line of the meridian is a line connecting a point of North-South points of the zenith, Horizon: a circular boundary between heaven and Earth, and Azimuth coordinates indicate the direction of view and altitude showed high star. Azimuth angle measured from the North point moving clockwise (North-East-SouthWest) so the North $=0^{\circ}$, East $=90^{\circ}$, South $=180^{\circ}$, West $=270^{\circ}$ angle and altitude (height) measured from the horizon toward the zenith, zenith so $=90^{\circ}$, nadir $=-90^{\circ}$.

Based on the description above, needed a simple tool that can help students in making observations of astronomical objects in order to deepen the students knowledge on course of IPBA. Therefore, done research with the title "The Developing of Prototype Tool Determining Celestial Positions (WAH 1.0) as Learning Media in Earth and Space Science Course ".

\section{Research Methods}

The Developing of Prototype Tool Determining Celestial positions of WAH 1.0 as a media of learning Earth and Space Science based on the flowchart in Figure 2. The process includes the creation of design tools, creation tools, testing tools, and analysis tool trial results.

Creation of design tools can be seen in table 1. In the process of making Architecture Tool Determining Celestial Positions REV. 1.0 required tools and materials required in deciding the position of tool making celestial REV. 1.0: compass, bows, Board size of $25 \times 25 \times 10$ $\mathrm{cm}$, Board size $5 \times 20 \times 10 \mathrm{~cm}$, wood glue, tripod, water pass and ruler.

The workings of the tool that is used to measure the magnitude of the compass angle of azimuth. The bow is used to measure the magnitude of the angular altitude. Water pass used so that instruments are in a horizontal position because if not in horizontal position, then the measurement of the angle of the altitude will not picture accurate the deciding tool position of heavenly bodies. 


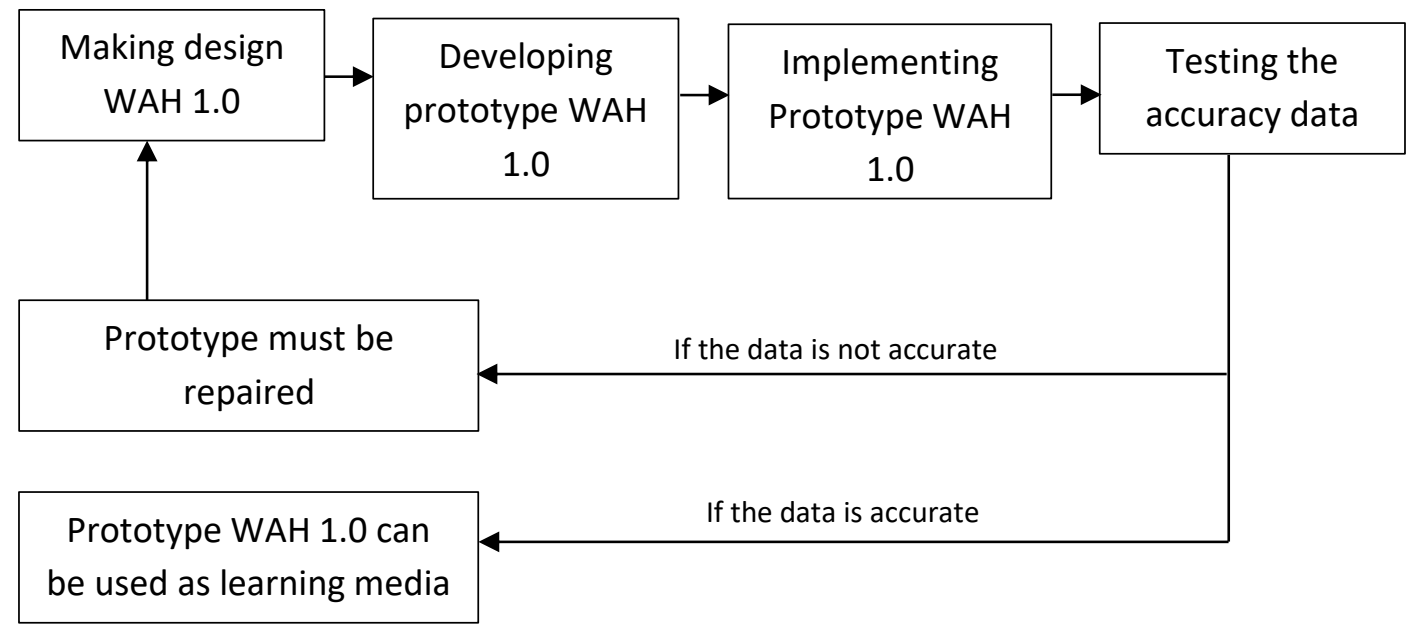

Figure 2. Research Design

Table 1 Determining the position of tool Design luminaries WAH 1.0

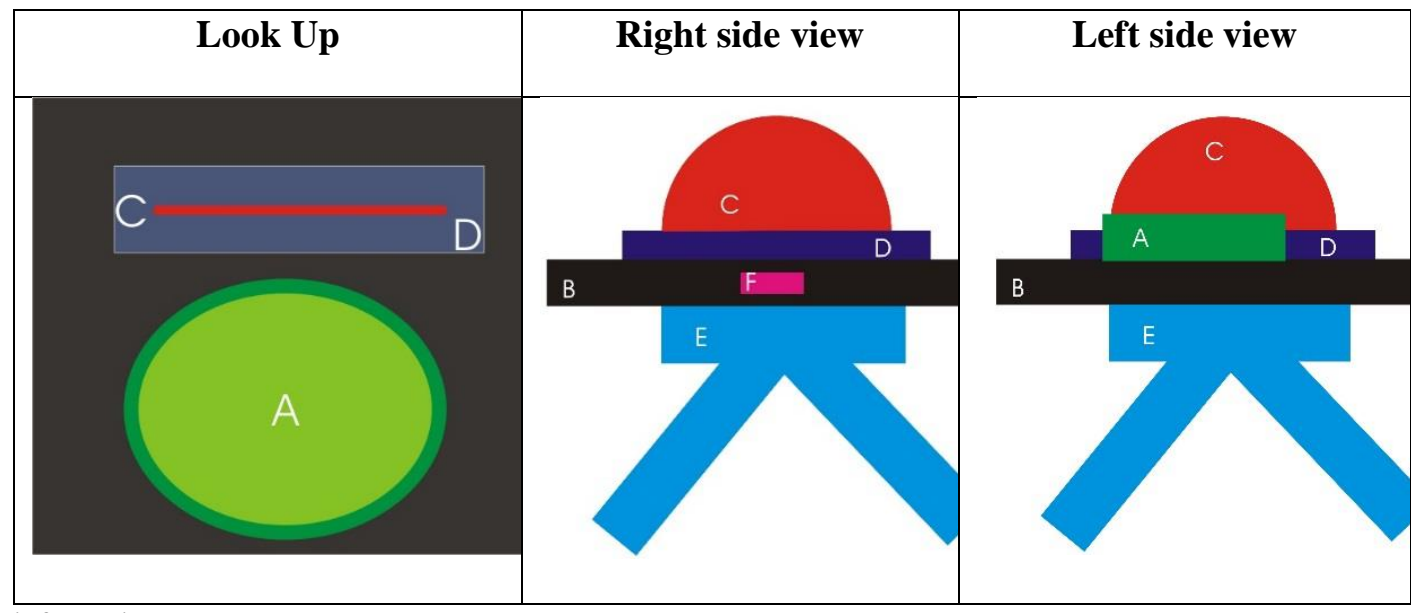

information
A: $\quad$ Compass
B: $\quad$ Board size $25 \times 25 \times 10 \mathrm{~cm}$
C: $\quad$ Bow

D: $\quad$ Board size $5 \times 20 \times 10 \mathrm{~cm}$

E: Tripod

F: Water pass 
Table 2 Photos Realization Design Tool Defining the position of the heavenly bodies WAH 1.0

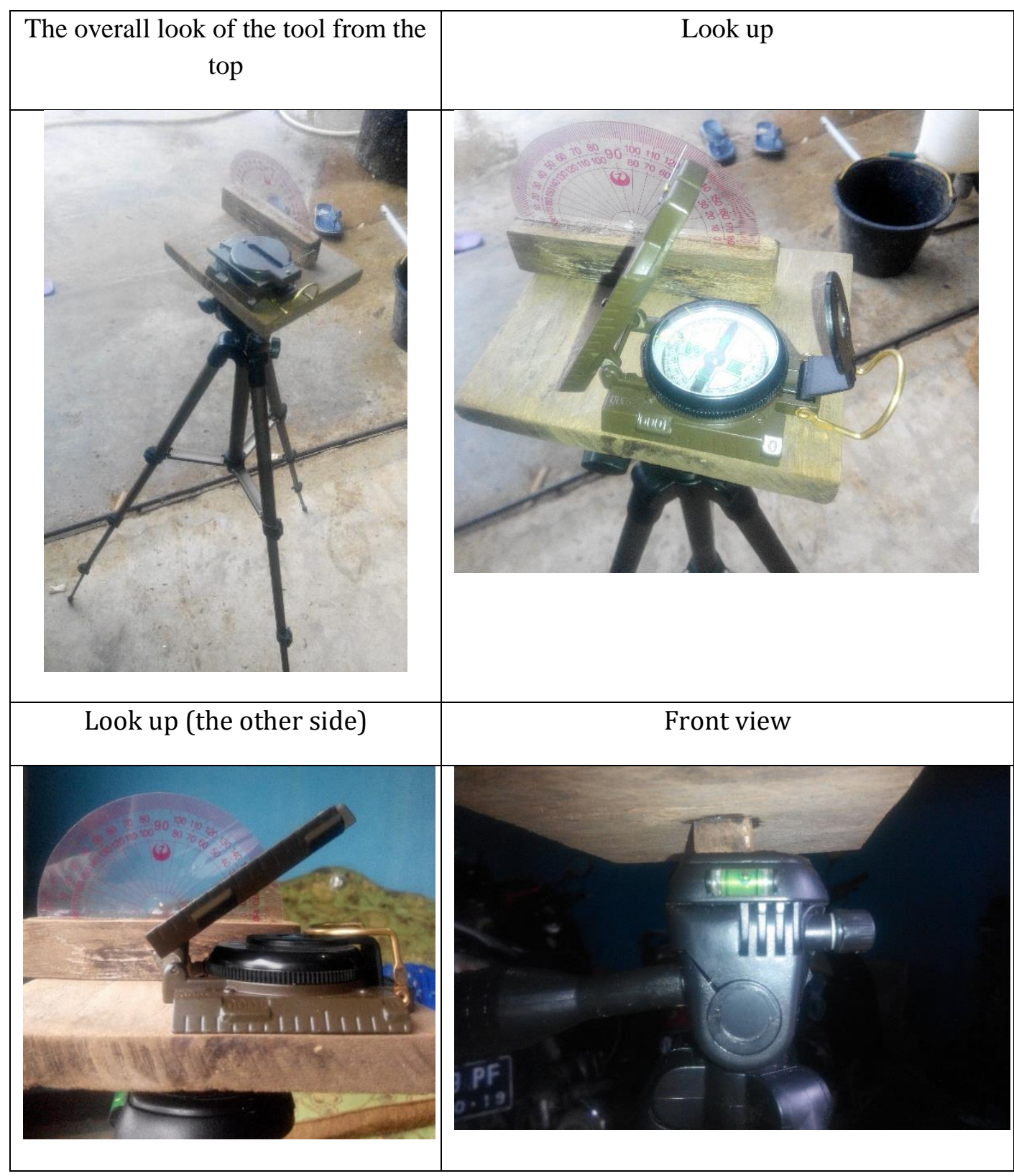




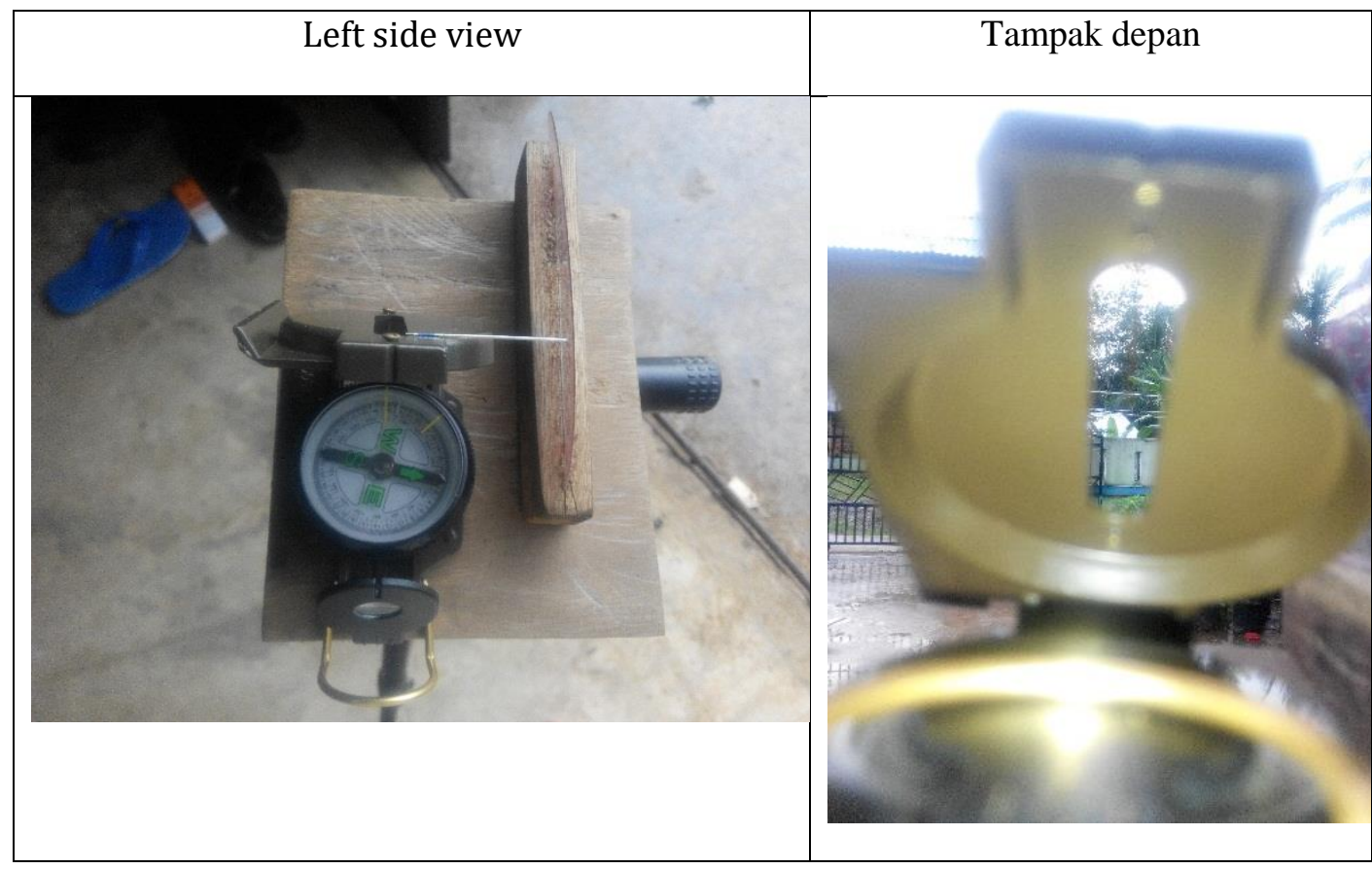

\section{Results and Discussion}

Trial results of tools that have been made do for celestial observations. The process of observation using the object as an object of observation of the Moon at night. Observations of the Moon made at the time the Moon is in perfect phase. Based on the observations obtained data in table 3 .

Table 3 The Observations Results of Astronomical Objects

\begin{tabular}{lllll}
\hline $\begin{array}{c}\text { The place of } \\
\text { observation }\end{array}$ & \multicolumn{1}{c}{$\begin{array}{c}\text { Date of } \\
\text { observation }\end{array}$} & $\begin{array}{c}\text { Time of } \\
\text { observation }\end{array}$ & $\begin{array}{c}\text { Azimuth } \\
\text { observation }\end{array}$ & $\begin{array}{c}\text { Altitude } \\
\text { observation }\end{array}$ \\
\hline & $21: 13$ & $122^{0}$ & $59^{0}$ \\
& June 7,2017 & $22: 00$ & $136^{0}$ & $68^{0}$ \\
$\begin{array}{l}\text { Pagar Agung } \\
\text { Village, West }\end{array}$ & $23: 00$ & $176^{0}$ & $75^{0}$ \\
$\begin{array}{l}\text { Seluma Sub Distric, } \\
\text { Seluma Distric, } \\
\text { Bengkulu Province }\end{array}$ & June, 82017 & 22.00 & $112^{0}$ & $51^{0}$ \\
& & 23.00 & $122^{0}$ & $64^{0}$ \\
& & $239^{0}$ & $74^{0}$ \\
\hline
\end{tabular}




\begin{tabular}{lllll}
\hline $\begin{array}{c}\text { The place of } \\
\text { observation }\end{array}$ & $\begin{array}{c}\text { Date of } \\
\text { observation }\end{array}$ & $\begin{array}{c}\text { Time of } \\
\text { observation }\end{array}$ & $\begin{array}{c}\text { Azimuth } \\
\text { observation }\end{array}$ & $\begin{array}{c}\text { Altitude } \\
\text { observation }\end{array}$ \\
\hline & $22: 30$ & $105^{0}$ & $34^{0}$ \\
& $\begin{array}{l}\text { June, } 11 \\
2017\end{array}$ & $23: 38$ & $108^{0}$ & $49^{0}$ \\
& & $23: 50$ & $109^{0}$ & $52^{0}$ \\
\hline
\end{tabular}

This research uses the moon as an object of observations of astronomical objects because the month is easily observed from Earth. The data from table 3 can then be illustrated in the graph in Figure 3 and 4 once done testing accuracy.

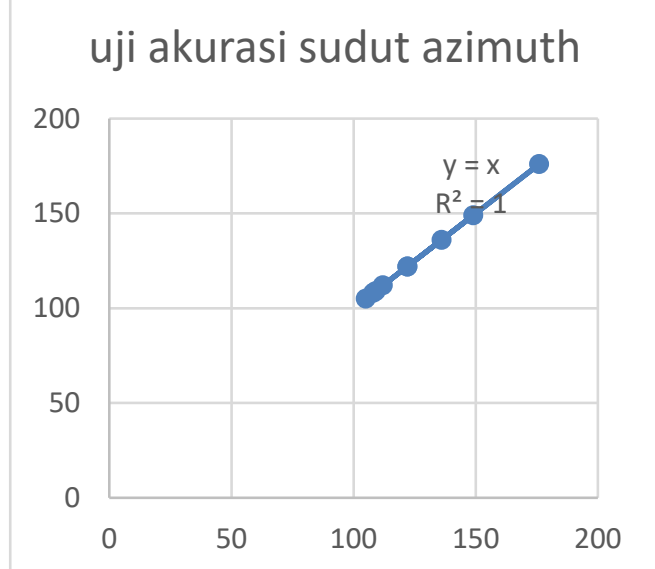

Figure 3 Test the accuracy of the angle of azimuth between observation and stellarium

\section{uji akurasi sudut altitude}

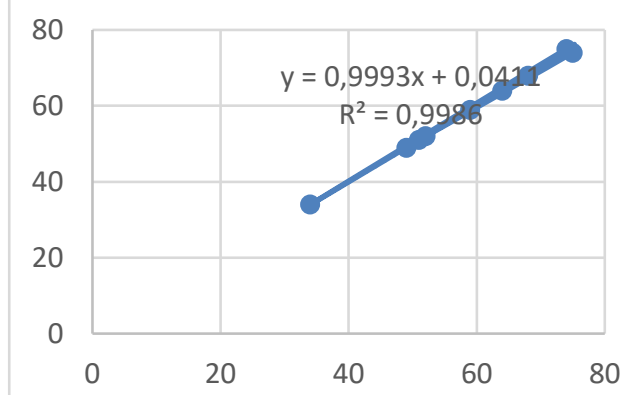

Figure 4 Test the accuracy of the altitude angle between observation and stellarium
In this study, the results of observations are then tested its accuracy levels with application applications stellarium mobile version 1.25. This software is an application that is already widely used as a comparison to other researchers and application is easily obtained. Based on test results obtained by the altitude angle accuracy that the equation of the graph is $y=x$ and $R 2=1$ where this indicates that the level of its accuracy $100 \%$. Meanwhile, to test the accuracy of the altitude angle obtained is graph equation $y=0,9993 x+0,0411$ with $\mathrm{R} 2=0.9986$ which have meaning that degree of accuracy determining celestial positions tool WAH. 1.0 for angle altitude reached $99.86 \%$. The cause of accuracy levels not reached $100 \%$ for the measurement of the angle of altitude is because the observations are still done manually (naked eye) so that if the heavenly bodies had already reached the position of $>600$ maka is already difficult enough. But with the level of accuracy of $>99 \%$ reach then surely the determining celestial positions tool WAH. 1.0 can be made and deserves to be used to determine the position of the heavenly bodies so that it can be used as a medium of instruction in the subjects of Earth and Space Science. 


\section{Conclusions and Suggestions}

Determining the position of heavenly bodies tool WAH. 1.0 can be created and used to determine the position of the heavenly bodies so that it can be used as a medium of instruction in the subjects of Earth and Space Science.

After doing research, the researchers gave advice for the use and development of this tool in the future: 1) Observations conducted on a sunny sky conditions because if the cloudy then it will be difficult. 2) these tools still use the system only for the measurement of degrees of altitude and azimuth, yet system using hours, minutes and seconds of arc, and 3) this tool still need refinement to gauge the magnitude of the degrees altitude.

\section{Reference}

Depdiknas. (2002). Pengembangan Sistem Pendidikan Tenaga Kependidikan Abad ke-21 (SPTK-21), Jakarta: Departemen Pendidikan Nasional.

Hambali, S. (2012). Pengantar Ilmu Falak, Semarang: Etose Digital Publishing.

NRC. (1996). National Science Education Standars, Washington D.C: National Academy Press

Pujani, N.M., dan Liliasari. (2011). Deskripsi Hasil Analisis Pembelajaran IPBA sebagai Dasar Pengembangan Kegiatan Laboratorium Bagi Calon Guru. Makalah pada Seminar Nasional Pendidikan. FKIP Unila, Bandar Lampung. 29-30 Januari 2011.

Purwanto, B. (2011). Pentingnya Kreativitas Guru dan Calon Guru Fisika Sma Dalam Upaya
Pengembangan Dan Pengadaan Alat Demonstrasi/Eksperimen Untuk Menjelaskan Konsep Dasar Fisika. Prosiding Seminar Nasional Penelitian, Pendidikan dan Penerapan MIPA. FMIPA, Universitas Negeri Yogyakarta, 14 Mei 2011.

Rustaman, N.Y., Dirdjosoemarto, S., Yudianto, S.A., Achmad, Y., Subekti, R., Rochintaniawati, D., dan Nurjhani K., M,. (2005). Strategi Belajar Mengajar Biologi. Malang: UM Press

Wulandari, A. Y. R. (2015). Pengembangan Media Pembelajaran Ipa Berbasis Animasi Komputer Menggunakan Program Macromedia Flash 8. Jurnal Pena Sains. Vol 2 No. 12015. 